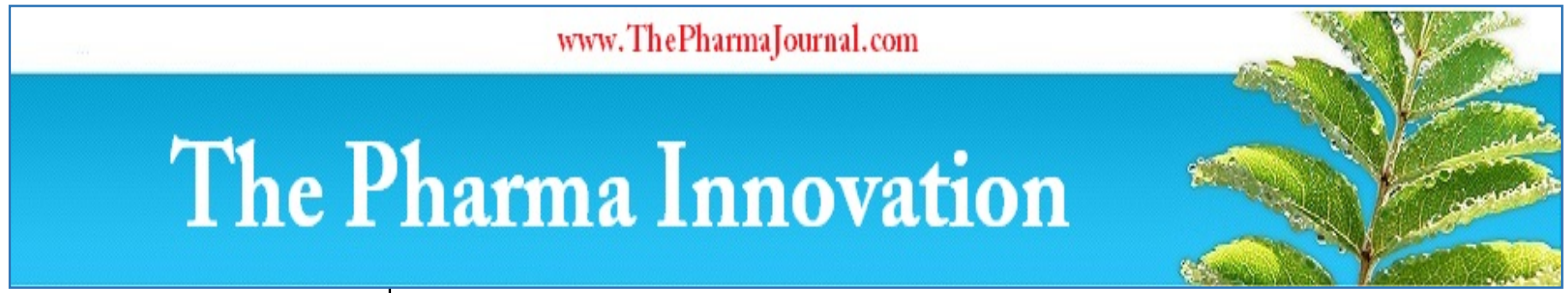

ISSN (E): $2277-7695$

ISSN (P): 2349-8242

NAAS Rating: $\mathbf{5 . 2 3}$

TPI 2021; SP-10(7): 462-468

(C) 2021 TPI

www.thepharmajournal.com

Received: 04-05-2021

Accepted: 06-06-2021

Bijoylaxmi Bhuyan

Assistant Professor, College of

Community Science, AAU,

Jorhat, Assam, India

\section{Dr. Indira Barua}

Former Professor and UGC

Emeritus Fellow, Department of

Anthropology, Dibrugarh

University, Assam, India

Dr. Deepanjana D Das

Former Associate Professor,

Department of Anthropology,

Dibrugarh University, Assam,

India

\section{Socio-cultural, demographic and health aspect of the Bodo tribals: A study on women}

\author{
Bijoylaxmi Bhuyan, Dr. Indira Barua and Dr. Deepanjana D Das
}

DOI: https://doi.org/10.22271/tpi.2021.v10.i7Sh.6948

\begin{abstract}
Livelihood of Bodo tribal depends mainly on agriculture and allied activities. In general a tribal society has some salient features in its socio economic spheres. The Bodos too have some unique socioeconomic features, which might be responsible for their demographic behaviour. This study was taken up to focus at tribal farm women's role in different socio cultural aspect and their health status. According to Bhasin, 2007, when primary and secondary subsistence activities are counted, women work more than men. During the study it was observed that amongst younger respondents 32, 13 and 22 pc suffered from back, shoulder and body pain of mild intensity respectively. Similarly, amongst elderly respondents, 80, 33, 60 and 30 pc suffered from back, shoulder, knee and over all body pain of mild to moderate intensity respectively. The ' $r$ ' values indicated that back pain had shown highly significant association with BMI in women of both the age groups. Similarly, knee pain and shoulder pain in elderly respondents showed highly significant association with BMI and was non-significant in younger age group. In the present study, 47.6 and 26.4 pc of younger and elderly respondents respectively belonged Ectomorphic body type.
\end{abstract}

Keywords: socio-cultural, demographic, body mass index, body type

\section{Introduction}

North-Eastern region of India is a melting pot of multi-ethnic and multi linguistic groups. This region is the habitation of a good number of tribes that are far from uniform in terms of their dialect, culture and custom. The schedule tribes of north east India can be broadly categorised in two heads, namely, the hill tribes inhabiting in the hills of Arunachal Pradesh, Mizoram, Meghalaya, Nagaland, Manipur, Tripura, hill districts of Assam, and the plain tribes settling in the valley areas of Assam particularly in the Brahamputra valley. There exists distinct socio cultural diversity within and between hill tribes and plain tribes. Apart from them there resides a very large percentage of population who are non tribals. North-East India is the home for more than 166 separate tribes speaking a wide range of languages. As per 2011 census, total population of Assam was 31,169,272. There are 23 notified scheduled tribes (ST) in Assam with the Bodos (44.5 pc) making half of the total ST population (around $13 \mathrm{pc}$ ) of the state. The other STs (both plains and hills) include Bodos, Mishings, Karbi, Rabha, Kachari, Lalung, Tiwa, Barman in Cachar, Borokachari, Deori, Mech, Dimasa etc. Kokrajhar is one of the twenty seven districts of Assam and can be described as the gateway to the north eastern region of India. Kokrajhar district is located on the north bank of the river Brahmaputra that slices the state of Assam into two, identified as north and south banks. The district can be easily reached as both the mainline road and rail passes through this district. The colourful Bodo community is one of the major dominant tribes of Assam with a definite ethnic identity and unique cultural pattern distinct from other tribes and is the integral part of the state and comprises the majority in Kokrajhar district. In 2011, Kokrajhar district had population of 886,999 of which male and female were 452,965 and 434,034 respectively. There was change of 5.19 pc in the population compared to population as per 2001. In the previous census of India 2001, Kokrajhar district recorded increase of 14.49 pc to its population compared to 1991 which was due to migration from other districts of the state. Traditionally social norms favour males over females this tradition has affected women to a great extent. The extent of effect on women can be answered with empirical research and are appropriate for development of the women's movement. Study of socio cultural factors helps to understand the beliefs, value systems, attitudes, interpersonal relations and experiences, problem solving, stress coping strategies etc. On the other hand the study of demography is of immense importance to an economy.
Corresponding Author: Bijoylaxmi Bhuyan Assistant Professor, College of Community Science, AAU, Jorhat, Assam, India 
Status of health is an important issue to focus at to direct plans and programs for improvement of the economic status of the farming population. Many people are leaving their farms because of low returns and extreme labour. In this age of technology and precision, efficient working for enhancing productivity in farm and in allied sectors of the tribal household is the need of the hour. Giving due consideration to the socio cultural aspects, health and wellness if proper drudgery reducing improved tools and technologies are popularised among this population lot of drudgery can be minimised and would help in better nutritional status and improve their economic status. So, in this present study an effort has been made to understand few socio-cultural aspects of the Bodos women's role and performance, the demography, their Body Mass Index and health problems in the reference area. Understanding of these aspects would help to direct different plans and programs of the government in a suitable way for the upliftment of economic status of the women in particular and the tribal people in general.

\section{Methodology}

Present study was undertaken in six Bodo villages with sizable Bodo population and at a distance of about 12 to 20 $\mathrm{km}$ from Kokrajhar town. Villages were purposively selected after proper observation containing largely agrarian population with different landholding categories with higher women participation of different age groups in various work. A total of 500 women were selected from the above population as target group belonging to the age group of 2565 years. Female population of this age group actively participated in various home, farm and allied activities however, slight decreasing trend in participation in work was seen slowly beyond 45 years. This partially conforms to the report of Rana et al. (2001) ${ }^{[8]}$, that population of the group between 30 to 50 years is believed to be more active in various farm operations. Respondents were grouped into two as younger women (25-45 years) and elderly (45-65 years). Data collection was done through observation, field experiments and personal interview using interview schedules to elicit information on some socio-cultural characteristics, demographic information, and perception of any occupational health hazards due to work, anthropometric data indicative of BMI and body type of the respondents.

Assessment of Body Mass Index and Body Type of the respondents was done using the following anthropometric measurements:

1. Weight (in kg)

2. Height/Stature (in $\mathrm{cm}$ )

Body Mass Index was computed using height and weight of the respondents

Body Mass Index (Quetlet's Index) $=\frac{\text { Weight }(\mathrm{kg})}{\operatorname{Height}^{2}(\mathrm{~m})}$

Classification of body types on the basis of BMI score According to Garrow’s scale (Garrow, 1985) ${ }^{[3]}$

Ectomorph $<21.5$

Mesomorph 21.5 - 25

Endomorph $>25.0$

\section{Results and Discussion \\ Socio cultural aspects of the Bodos of the selected area Religious festivals}

Religion has emerged as one of the important medium of transformation in the Bodo community. People follow different sects like Brahma Bathou, Bathau Shiva Dharma Sangha and Bodo Bathau and amongst these the oldest is Bodo Bathau dharma. The followers of Brahma religion observe many traditional rituals. There are lot of differences between followers of Brahma and non-Brahma religion. Specially, the Brahma Bathou and Bathau Shiva Dharma Sangha are fire worshipers and perform yogya and offer ahuti. They neither sacrifice animals nor offer rice beer to gods instead they practice Vedic rites as followed by other Hindus. On the other hand, Bathau followers sacrifice birds and animals like cock, pigeon, goat and pig besides offering rice beer (jau). Christianity and Joyguru or Anukul sect of Hindu religion are followed by fewer percentages of Bodo people. Now the influence of new religion called Brahma Bathou and Bathau Shiva Dharma Sangha is deep. The followers of these sects of religion have reformed and have bought significant cultural change in the Bodo society. The Siju plant (Euphorbia splendens) is considered as the image of the supreme deity Bathou. Bathous consider the Bathou Borai as the chief god. According to them $\mathrm{Ba}$ means five and thou means deep, hence Bathou means five 'spiritual entity'. Kherai is the greatest religious ritual of the Bodo Bathou people, here goddess Lakhsmi is mainly worshiped along with other gods. It is expensive and elaborate. Kherai is performed in family and in community level for the welfare of both. Noaoni Kherai is performed in family level and there is no fixed time for this, whenever the family wants to perform Noaoni Kherai can do. On community basis Kherai can be observed in September-October (Kati), or July-August (Ashar) or in January-February (Magha), worship of Kherai continues for three days. There is no fixed place for this. They sacrifice animals or birds to the gods in the Kherai. Another important festival of the Bodos is Garja puja where rituals are performed to protect the villagers from epidemics. A person is purified of his/r sinful act by performing Garja puja. The New Year festival called Baisagu is observed in mid-April and is a popular festival. During this festival, apart from doing other rituals, boys and girls go around the villages to collect rice, pulses and money. They continue this until they arrange a picnic. Domashi is another popular festival which is observed after harvest i.e. during mid-January. They also observe rituals like Hapsa hatarnai in New Year in the month of April, Domashi in January, ceremonial feast of rice from the new harvest is done in a function called Awnkham Gwrlwi Janai. In very religious activity women's role was indispensable.

\section{Society}

In general, tribes are indifferent with respect to education due to socio economic conditions. They prefer to send their children up to a certain level if education helps to increase productivity. But it is of paramount importance to impart education, knowledge to the poor farming section of the population so as to develop them socially, economically with justice to make them part and parcel of the total development of the society. Caste and dowry are not practiced by the Bodos. Majority of them are lagging behind because of illiteracy and ignorance. The literary rate of the Bodo dominated Kokrajhar district was 65.22 pc in 2011 which was 52.29 in 2001 against the state average of 72.19 pc in 2011. However with the changing environment, education has received greater importance among the masses which has been reflected in their increasing participation in state politics 
however women's participation was not apparent.

\section{Food habits}

Dietary habits are responsible to a great extent for health status of the tribal population. That in turn influences fertility and mortality levels. Being agriculturist their diet is well supplemented by a variety of vegetables, meat, fish, eggs etc. Besides cultivation of different vegetable crops they are accustomed to collecting wild vegetables of different tastes, some of which are treated as medicines as well. Originally the Bodos were very fond of animal meat and fish. The Bodo households under study were non-vegetarian and rice was their staple food and was often accompanied by a nonvegetarian dish such as fish or pork or chicken. Pork (Oma bedor) is an important item of dietary menus. But they do not eat beef and meat of buffalo. They prepared pork meat with different flavours and style. It could be fried, roasted (smoked) and stewed or drying of the meat in the sun for several days or cooked by mixing pork blood and meat called Oma khaji. Another dish of fish Napham made by grinding smoked fish and mixed with certain leafy vegetables and the mixture was allowed to age in a sealed bamboo cylinder and eaten by adding in curries or making chutneys. Onla a gravy made from rice powder and slices of bamboo shoots cooked lightly with oil and spices. Chicken or pork could be added to Onla. Apart from these they ate lots of vegetables by stewing as well. Traditional favourite drink of the Bodos was $Z u$ Mai ( $\mathrm{Zu}$ : wine, Mai: rice). A special kind of rice beer customarily brewed in every household is of great use in Bodo society and they serve this to guests. This beer has essential place in social and religious function. Besides they take a cup of rice beer to get relief from mental and physical fatigue. It was encouraging to see that many people were prohibited from making the drink at home or selling by Bathou religious followers, but, it is yet to be followed strictly. Food processing, preservation, daily cooking and serving activities were the sole responsibility of the women of the household.

\section{Costumes}

Dresses of the Bodo tribal community is quite exquisite, thereby, exhilarating the beauty and glamour of females to a wide extent. Bodos wear the traditional, colourful and beautiful dresses woven by the women at home. The conventional dress of a Bodo female is popularly known as dokhona. Men use big gamocha like material to wear at home, otherwise wear dhoti with chaddors. But, now a day's all men wear trousers and shirts. In winter, they wear thickly woven endi shawls. While going out of home or for greeting people they wear a cloth named arnai which is wrapped around the neck and is an important part of their custom it is also used to greet guests to confer honour.

\section{Status of women}

Though patriarchal, the place of women in Bodo society is significantly high. If there is no male child in the family, property is distributed among the daughters and they can enjoy the property even after marriage. If there is one female child than the entire property goes to her after the death of her parents. Like many other patriarchal societies, Bodo family also prefers to have a male child, but female child is also not recognized as inferior to male child. Before marriage girls are allowed to take part in any festive occasions, moving outside with family, relatives and friends. One can observe that the
Bodo young girls moving around in local markets for shopping and other purposes. Elderly women were seen selling locally grown organic vegetables and pulses etc. in the market place and this used to be an important income generating activity for them.

\section{Bodo women and domestic work}

Women's role is defined by household demand and is a fact in most societies. Traditionally in Bodo society, the women are responsible for all the household activities assisted by her unmarried daughters and young aged sons. The Bodo women since dawn to dusk are engaged in unending tasks. These include besides child rearing and caring, domestication of animals, making household products, cooking, washing, cleaning homestead etc. The Bodo women are engaged in multiple chores throughout the day. The young girls and women remain busy in weaving at their individual household as well as in newly formed weaving centres. Women of middle age are hard workers and do lot of work in their daily life cycle.

\section{Occupation and economy}

Occupation and economy as indispensable sub-system of social structure to a great extent is influenced by social environment and social structure. Bodos are predominantly agriculturists and their livelihood depends mainly on agriculture and allied activities. They are hardworking and possess the skill and physical ability to toil under the sun. They grow variety of crops. They carefully chose the plot of land for cultivation judging the fertility and water availability. They construct irrigation canals and earth work embankments to supply water to paddy fields from rivers. Apart from rice, cultivation of jute, mustard, various types of fruit crops, spices, vegetables etc. is also under taken by the Bodos. Though the agriculture practiced by the Bodos is subsistent in nature but it still brings some relief to the economy to the households. Studies revealed that, tribals are late adopters of new farm practices. Even the big farmers do not come forward easily to adopt new practices. The tools used in agricultural activities are nangal, moi, phai, kasha, dao etc. Besides this, animal husbandry, poultry, fisheries etc. are other income generating sources. Men folk of the tribe practice bamboo and cane work as a subsidiary source of income. They can artistically produce variety of items made of bamboo and cane such as furniture, fishing appliances etc. Bodo women's contribution was obligatory in farming activities of all crops, they took part in many activities with traditional simple tools and implements during farming season.

\section{Cottage industry and ancillary activities}

Cottage industry occupies a paramount place in the socioeconomic life of the Bodos. But, the tools and the implements used in the cottage industries were simple that include handloom weaving, bamboo work. They rear varieties of silk worms viz., endi, muga and pat. Bodo women produce muga and endi products using traditional tools implements and without a big capital. Thus weaving and sericulture play an important role in the economy of the Bodos.

\section{Silk farming}

Rearing of silk worms by women is prevalent in the area as a part of leisure time activity in addition to various household and farm activities. The eri/endi silk worm rearing was 
conducted not only for its silk but also for consumption of pupa as one of its delicacies. It is another subsistence economic activity involving traditional method of rearing usually done by the elderly women of middle age and onwards. They start this activity in the month of January and continue till June during the lean farming period. This activity of rearing endi silk worms is undertaken by women in groups of four two five members that involves collection of either adult butterfly or eggs of the worms from locality of availability, taking care in egg laying and hatching, making of bamboo structure for hanging of the feeding materials, collection and carrying of castor leaves for feed from distant places, cleaning excreta and taking every care throughout the cycle for preventing mortality of the worms. During this entire period from January to June, they harvest worms and cocoons for 4-5 times as one cycle takes 40 to 45 days for completion. The matured pupae were sold in local market at a meager price of Rs. 200 per kilogram. It is learnt from prevailing market sources that middlemen, who collected the cocoons at one fifth of market price of Rs. 900 to Rs. 1000, exploit the women due to their ignorance and lack of enterprising acumen. Some of the women were given half the market price if they were aware enough to bargain. The women in endi silk worm rearing activity were thus under paid and the benefit of their labour is reaped by the middlemen. Thus, the group of elderly women involved in endi silk worm rearing fetches a cash of Rs. 4000 to Rs. 5000 which they divide amongst themselves. On the contrary, adoption of capacity building in rearing with modern techniques and effective awareness on marketing of the cocoons would have fetched them better price.

\section{Weaving}

Bodo women folk also significantly contribute to their family income by weaving beautiful and fine quality fabrics. Weaving is compulsory for young Bodo girls. They learn the technique of weaving in early age like all other communities of Assam. Traditionally they wove all the clothes required for a family like dokhona, aranai, gamocha, man's wear, bed covers etc. by themselves, apart from clothes for wedding. Generally weaving is done in winter. Now-a-days, weaving as a commercial venture has turned into a round-the-year activity of the Bodo women folk and has generated income to the household economy.

\section{Animal rearing}

A cow shed near home is a symbol of prosperity. Everybody tries to keep cows and bullocks at home. Bullocks are used for ploughing. Domestic animals like goat, pig and birds like hen and duck are also reared. Religion has some influence in domesticating animals. Earlier, pigs were important domestic animals, but, followers of Anukul/Joyguru sect of Hindu religion and Brahma Bathau were opposed to rearing of pigs. This practice started in the beginning of the $20^{\text {th }}$ century. Even though rearing of pigs is not permitted yet, many followers of Brahma Bathau do rear pigs and eat. They also rear animals in adhi system (i.e. the owners gets half of the income from the animals/birds). In case of cows, the person who looks after these get the calf, whereas, the owner gets a greater share of milk.

\section{Fishing}

Fishing is another important activity of the Bodo women. During the rainy season they go for fishing regularly. They fish in fields, marshy lands, rivers, streams etc. They catch fish with the help of jakoi (conical shaped artifact made of split bamboo) and khaloi (pot made of bamboo which is tied around the waist to put the caught fishes). This is a very favourite sport of the Bodo women.

\section{Post-harvest activities}

It is customary to use udal for the purpose. Now, since, husking mills are a common feature in the rural areas, women are relieved from doing this arduous task regularly. Husking mills saved time and energy of the young rural women. Pounding still continues in small scale in various households. The cultivation of other cash crops like mustard, sesame, maize and jutes are also done by them with considerable participation of women in post-harvest activities along with men. Young girls and women now utilize their time and energy in pursuing other income generating activities and in study.

\section{Demographic features of the Bodos under the study}

In order to understand the composition some basic demographic features of the Bodo population of the six villages few characteristics were studied and the analysis revealed the following - the number of households of the six villages ranged from 51 to 108 , the total population was enumerated at 3162. It was revealed that male and female population comprised of 52 pc and 48 pc respectively with male-female ratio of $1000: 923$. With regards to sex ratio in Kokrajhar district, it stood at 958 per 1000 male. The average national sex ratio is 940 as per latest reports of Census 2011 Directorate. The lower sex ratio in the study area was natural and had no anti-social causes like sex discrimination, prenatal sex determination and female infanticide or foeticide as evident in certain societies. Regarding literacy level of the respondents, it was found that 19 pc of total population were illiterate followed by 27 pc who completed primary level of education. Study further showed that quite a sizable percentage of the population read up to high school (25 pc) and higher secondary (19 pc) level. However, only a small percentage of the total population was graduates (8 pc) and post-graduates (2 pc). As regard to annual cash income of the households it was revealed that out of 500 households majority (42.6 pc) belonged to low income group followed by medium level of income (37.2 pc) and rest in high income group. This indicated that sizeable numbers of households under study were economically weaker. The study on distribution of population based on religion revealed that majority of the respondents followed Bathau Shiva Dharma Sangha (34 pc) and Brahma Bathau (27 pc) which combines to constitutes $61 \mathrm{pc}$, followed by Bodo Bathouism (29.3 pc). A small section of the population followed Anukul/Joyguru sect of Hinduism (5.5 pc) while only 4.0 pc of the population were Christians. Findings on occupation of the respondents revealed that $42.0 \mathrm{pc}$ and $48.0 \mathrm{pc}$ of younger and elderly respondents respectively reported having their own farmland and farming as their primary occupation (Fig. 1.). Petty trading was reported to be the primary occupation of 12 percent younger and 23 pc elderly respondents.

With respect to subsidiary income generation 37 pc of younger and $18 \mathrm{pc}$ of elderly respondents were engaged in weaving followed by about 20 pc of younger and 34 pc of elderly women in farming. While about $10 \mathrm{pc}$ of younger and 4 pc of elderly respondents were found to have engaged in some kind of services as primary occupation and about $12 \mathrm{pc}$ 
and 5 pc respectively as secondary occupation in Govt. or private organizations.

In general, the farmers under study practiced traditional method of cultivation using traditional ploughs and indigenous bullocks as draft animal for tilling their land. Very rarely they had buffaloes (0.8 pc). Mechanized agriculture was carried out to little extent in the sample population with only 14 numbers of tractors/power tillers in the area. On the other hand women also did manual work in the farms without any improved tools and technologies.

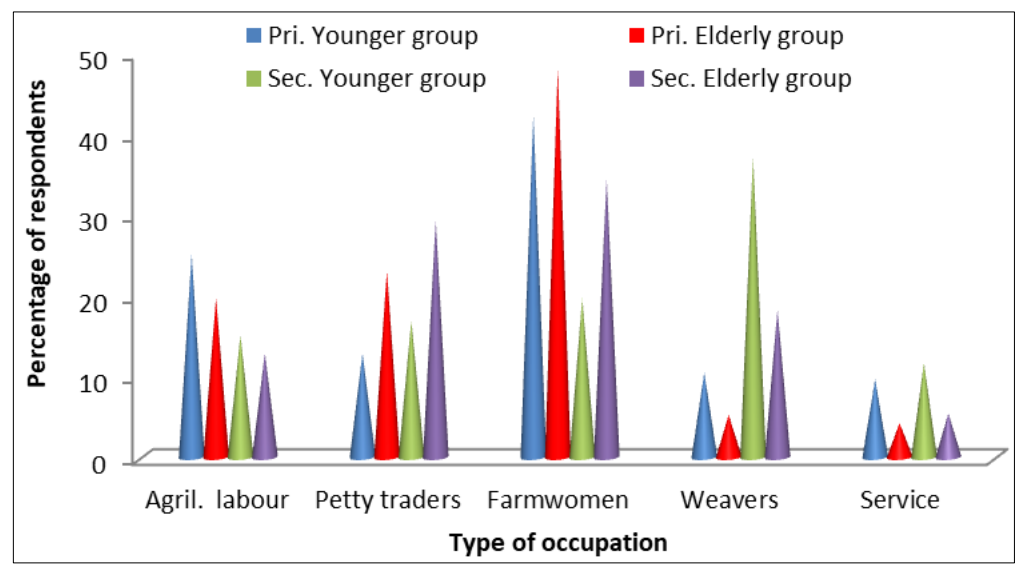

Fig 1: Distribution of the respondents based on occupation

Income of the respondents is defined as the remuneration received periodically for work or service performed by man/woman (Peppenocir, 1977) ${ }^{[10]}$. Income of the household plays an important role in determining one's economic status (Lodha, 2003) ${ }^{[11]}$. As household income increases household shifts from simple tools, supplies and equipment to complex ones (National Sample Survey, 2001) ${ }^{[12]}$. The study on family income showed that 45.2 pc of the households of younger and 60 pc of elderly group belonged to low income group (Fig. 2).

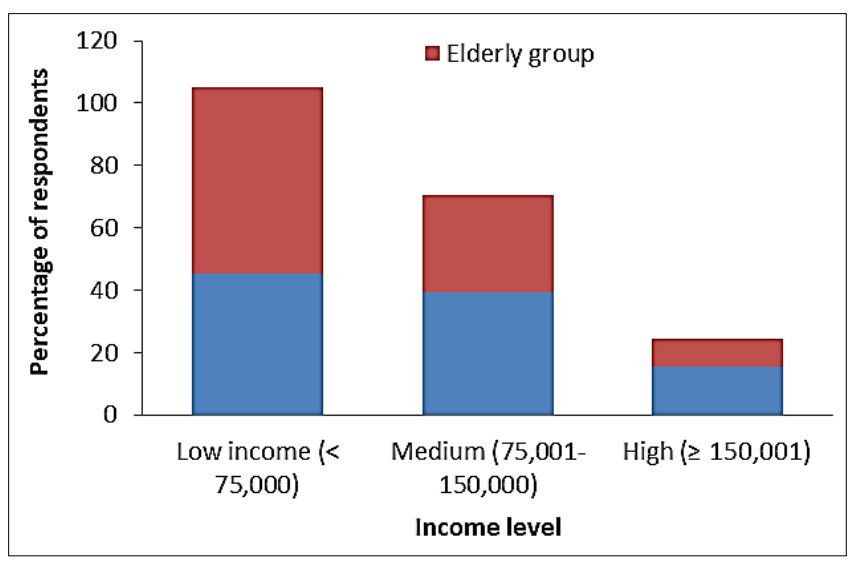

Fig 2: Annual cash income of the respondent households

Occupational health hazards of the respondents related to their involvement in different activities

The diverse spectrum of involvement of Bodo women in different activities were focused through the above observations. Effect of their work in health if any was assessed and revealed that majority of the respondents did not complain about any kind of body discomforts during work. Pain in the wrist, lower arm, headache and some minor ailments were over looked during work. In addition to aforesaid ailments, joint pain, backache, shoulder pain, knee pain, body ache, fatigue, sun burn, nausea, cuts, bites of insects, animals, snakes, urinary infection, stomach disorder etc. were reported to be some of the common problems of the respondents apart from fungal infections of feet, nails etc. It was observed that amongst younger respondents 32, 13 and 22 pc suffered from back, shoulder and body pain of mild intensity respectively. Similarly, amongst elderly respondents 80, 33, 60 and 30 pc suffered from back, shoulder, knee and over all body pain of mild to moderate intensity respectively (Table 1.). Most of the respondents denied work to be the reason for back and body ache rather they said it could be due to aging.

Other problems like fungal infection of toes and feet, insect bites, cuts were very common and used household remedies at time of severity. In course of the study, seven women in their later ages were found to have complete deformation of backbone and unable to stand straight. Various works undertaken by adopting improper postures and load bearing work throughout the life might be reasons of such permanent deformation of spinal cord.

Table 1: Assessment of occupational health hazards of Bodo women related to their involvement in different activities

\begin{tabular}{|c|c|c|c|c|c|}
\hline \multirow{2}{*}{ Sl. No. } & \multirow{2}{*}{ Type of body discomfort } & \multicolumn{2}{|c|}{ Younger group } & \multicolumn{2}{|c|}{ Elderly group } \\
\hline & & Percentage suffered & Relative weightage & Percentage suffered & Relative weightage \\
\hline 1 & Joint pain & 12 & 2.46 & 22 & 2.72 \\
\hline 2 & Backache & 32 & 2.86 & 80 & 3.40 \\
\hline 3 & Shoulder pain & 13 & 2.44 & 33 & 2.71 \\
\hline 4 & Knee pain & 09 & 2.49 & 60 & 2.69 \\
\hline 5 & Body ache & 22 & 2.63 & 30 & 2.82 \\
\hline 6 & Sunburn and nausea & 52 & 3.63 & 28 & 2.70 \\
\hline 7 & Fatigue & 62 & 3.04 & 68 & 3.10 \\
\hline 8 & $\begin{array}{l}\text { Infection in limbs and other body } \\
\text { parts }\end{array}$ & 12 & 2.44 & 19 & 2.87 \\
\hline 9 & Bites by insects, animals etc. & 34 & 2.45 & 29 & 2.61 \\
\hline
\end{tabular}


It was further observed that amongst younger respondents 52 pc reported frequent incidences of sunburn and nausea of moderate level because of performing farm activities under sun, 62 pc reported discomfort like physical fatigue of moderate level during peak loads and 12 pc reported incidences of joint pain of mild level.

Similarly, amongst elderly respondents 28 pc reported frequent incidences of sunburn and nausea of mild level, 68 pc reported fatigue of moderate level and 22 pc reported joint pain of mild level under similar conditions. Apart from these certain discomforts like infections and insect and animal bites affected both the groups (Table 1.). Report of Kishtwaria et al. (2004) asserted that majority of the respondents in their study suffered from severe low back pain due to squatting posture used for performing the weeding activity and very few of them suffered from pain in knees.

\section{Body mass index (BMI) of the respondents}

BMI is an anthropometric standard for defining the body composition of men and women. Initially it was used to measure obesity in developed countries, but it is now applied to both under and overweight adults in most countries of the world. The height and weight of a person is also indicative of one's fitness (Jhajharia, 2001) ${ }^{[7]}$. According to Deurenberg et al. (1991) 'BMI is an important aspect for determination of work capacity of an individual and asserted that, people who weigh less or more have low work capacity'. It is indicated in Table 2 that younger respondents with mean age, weight and height of 33.04 years, $51.63 \mathrm{~kg}$ and $152.51 \mathrm{~cm}$ respectively measured a BMI of 20.86. On the other hand, the elderly group respondents with mean age, weight and height of 53.98 years, $60.01 \mathrm{~kg}$ and $157.00 \mathrm{~cm}$ respectively measured a BMI of 23.71 .

Table 2: Parameters of body mass index of the respondents

\begin{tabular}{|c|c|c|c|c|c|c|c|c|c|}
\hline Sl. No. & Age group & $\begin{array}{c}\text { Mean age } \\
\text { (Yrs.) }\end{array}$ & \pm Sd & $\begin{array}{c}\text { Mean } \\
\text { weight (kg) }\end{array}$ & \pm Sd & $\begin{array}{c}\text { Mean } \\
\text { height (cm) }\end{array}$ & \pm Sd & BMI & \pm Sd \\
\hline 1 & Younger group (25-45) & 33.04 & 10.12 & 51.63 & 10.34 & 152.51 & 8.55 & 20.86 & 3.38 \\
\hline 2 & Elderly group (45-65) & 53.98 & 5.79 & 60.01 & 13.71 & 157.00 & 8.87 & 23.71 & 4.11 \\
\hline
\end{tabular}

The coefficients of correlation (r) between mean score of body discomforts with mean BMI score of both the groups have been presented in Table 3. The ' $r$ ' values indicated that back pain had shown highly significant association with BMI of elderly group at 0.01 level compared to younger group at 0.05 level. Similarly, knee pain and shoulder pain in elderly respondents showed highly significant association with BMI at 0.01 and 0.05 level respectively which was found to be nonsignificant in younger age group. The reason might be due to higher workload and adoption of awkward postures during work since young age might have resulted in increased pain in back and neck in elderly group. As it was also found in the study that, elderly women had higher BMI than younger which could be due to less active participation in work associated with body discomforts such as pain. Elevated risk of back pain has been observed in relation to obesity, particularly among women by Han et al. (1997) ${ }^{\text {[5]; Garzillo }}$ and Garzillo, (1994) ${ }^{[4]}$.

Table 3: Correlation between BMI and body discomforts in performing various activities by the respondents

\begin{tabular}{|c|c|c|c|}
\hline Sl. & Type of body & \multicolumn{2}{|c|}{ Correlation coefficient 'r' } \\
\cline { 3 - 4 } No. & discomforts & Younger group & Elderly group \\
\hline 1 & Joint pain & 0.026 NS & $0.105 \mathrm{NS}$ \\
\hline 2 & Backache/back pain & $0.164^{*}$ & $0.391^{* *}$ \\
\hline 3 & Shoulder pain & $0.119 \mathrm{NS}$ & $0.154^{*}$ \\
\hline 4 & Knee pain & $0.078 \mathrm{NS}$ & $0.278^{* *}$ \\
\hline 5 & Body ache & $0.097 \mathrm{NS}$ & $0.107 \mathrm{NS}$ \\
\hline 6 & Fatigue & $0.058 \mathrm{NS}$ & $0.015 \mathrm{NS}$ \\
\hline 7 & Sunburn/nausea etc. & $0.028 \mathrm{NS}$ & $0.097 \mathrm{NS}$ \\
\hline
\end{tabular}

**Significant at 0.01 level, *significant at 0.05 level and NS: nonsignificant

If task demands are excessive, pain may be experienced in the muscles providing the stabilization in the muscles and joints of the effectors, or in both. Over time medical condition may develop'. Same is the case with women as they were always involved in repetitive manual work with awkward posture.

\section{Classification of basic body types (Somatotypes)}

There are three basic body types, or somatotypes and refers to the underlying physique and are not changed by over eating or training. In fact, most people’s bodies are a combination of these somatotypes -

- Ectomorphs: They are tall and thin with low body weight and have high centre of gravity. Ectomorphs often take part in endurance activities. In the present study, 47.6 and 26.4 pc of younger and elderly respondents respectively belonged to this category (Table 4).

- Mesomorph: They are muscular with broad shoulders and narrow hips. Mesomorphs are often good at sports and activities that require power or strength. The study revealed that 40.40 and 34.4 pc of younger and elderly group respectively belonged to this category.

- Endomorph: They are short with narrow shoulders and broad and pear shaped hips and have a low centre of gravity. Endomorphs tend to be less mobile due to extra weight and therefore, less likely to excel at sports requiring speed and heavy activities. In the present study, 12 pc of younger and 39.2 pc of elderly group belonged to this category.

Table 4: Classification of body type based on body mass index (On the basis of Garrow's scale, 1985) [3]

\begin{tabular}{|c|c|c|c|c|c|c|}
\hline \multirow{2}{*}{$\begin{array}{l}\text { Sl. } \\
\text { No. }\end{array}$} & \multirow{2}{*}{ Body type } & \multirow{2}{*}{$\begin{array}{c}\text { BMI range } \\
\left(\mathrm{kg} \mathrm{m}^{-2}\right)\end{array}$} & \multicolumn{2}{|c|}{ Younger group } & \multicolumn{2}{|c|}{ Elderly group } \\
\hline & & & No & pc & No & $\overrightarrow{\text { pc }}$ \\
\hline 1 & Ectomorph & $<21.5$ & 119 & 47.60 & 66 & 26.40 \\
\hline 2 & Mesomorph & $21.6-25.0$ & 101 & 40.40 & 86 & 34.40 \\
\hline 3 & Endomorph & $>25.0$ & 30 & 12.00 & 98 & 39.20 \\
\hline
\end{tabular}

Despite these discriminating factors related to different body types, respondents of younger group performed the activities with same zeal giving greater stress on the body. This study conforms to the findings of Barker et al. (2006) ${ }^{[1]}$, that being a part of farming household is a factor contributing to the thinness of younger women. While in case of elderly group performance of work reduces with age resulting in enhanced BMI.

In a similar study by Kishtwaria et al. (2004) on distribution of women respondents according to body type among hill women of Himachal Pradesh, 57 pc were found to have Mesomorphic body type and 70 pc were found to have normal BMI. Where as in another study conducted in Dharwad by 
Hasalkar et al. (2004) ${ }^{[6]}$ had reported having more than 50 pc respondents with Ectomorph body type.

\section{Conclusion}

Considering the socio-cultural aspects on the backdrop, the day-to-day activities of the women had been analysed to highlight their involvement. From the study it can be concluded that Bodo Tribal women involved in diverse activities in day to day life. The Body Mass Index was determined and its relation with occupational hazards of the women was assessed and illustrated highly significant positive relationship with BMI in elderly women compared to younger women. Classification of physique of Bodo women respondents according to somatotypes helped to understand the types to which they belonged, majority of the younger women were in Ectomorph type $(47.60 \mathrm{pc})$ and majority (39.20 pc) of elderly were in Endomorph type. Like other women of various communities in Assam, Bodo women were bounded by different customs and traditions and took active role in its preservations and help to transmit it from generation to generation. Majority of them due to various reasons are still quite behind modern techniques of farm mechanization which is very important in today's context. Health care should be adequate to address issues of their problems, because healthy people only can lead a nation in the path of progress. Mechanization helps in introducing efficiency and enhances production in agricultural sector. It helps to increase time use efficiency for speedy accomplishment and simultaneously facilitate more than one activity, create newer opportunities for women as well in allied sectors there by improve the standard of living. Empowerment would help to bring rural tribal farm women into the mainstream of development and improve their economic status. The success of empowerment is directly related to the speed and method with which the women would be organized, trained and enriched in new ideas, which inculcates in them an urge for practicing the latest practices for better livelihood.

\section{Reference}

1. Barker M, Chorghade G, Crozier S, Leary S, Caroline F. Gender Difference in Body Mass Index in Rural Indian Are Determined by Socio-Economic Factors and Life Styles. The Journal of Nutrition 2006.

2. Borgohain A, Akand AH. Time Utilization Pattern of Tribal Women in Animal Husbandry. Indian Res. J Ext. Edu 2011;11(1):50-56.

3. Garrow JS, Webster J. Quetlet's Index $\left(\mathrm{W} / \mathrm{H}^{2}\right)$ as a Measure of Fitness. International Journal of Obesity 1985;9:147-153.

4. Garzillo MJD, Garzillo TAF. "Does obesity cause low back pain?” Journal of Manipulative and Physiological Therapeutics 1994;17:601-104.

5. Hans TS, Schouten JSAG, Lean MEJ, Seidell JC. "The prevalence of low back pain and associations with body fatness, fat distribution and height”. International Journal of Obesity 1997;21:600-607.

6. Hasalkar S, Budhihal R, Shivali R, Biradar N. Assessment of workload of weeding Activity in Crop Production through heart rate. J Hum. Ecol 2004;14(3):165-167.

7. Jhajharia A. Physical health and musculo-skeletal problems of rural women employed in selected occupations. Master's Dissertation, Unpublished.
Maharana Pratap University of Agriculture and Technology, Udaipur 2001.

8. Rana A, Sharma DD, Raina KK. Participation of hill women in decision making (A study of Himachal Pradesh). Rural Ind 2001, 205-207.

9. Veena Bhasin. Status of Tribal Women in India, Studies on Home and Community Science 2007;1(1):116. DOI: $10.1080 / 09737189.2007 .11885234$

10. Peppenocir. Sociology $3^{\text {rd }}$ ed. Prentice hall. Inc. Englewood cliffs, New Jersey 1977, 568.

11. Lodha N. Status of Tribal Women, Jaipur: Mangaldeep Publication 2003, 160.

12. National Sample Survey. Number of Households Using LPG Fuel in a Year. Ministry of Statistic and Program Implementation. Government of India, New Delhi 2001. 